\title{
MERGERS AND ACQUISITIONS ACTIVITY OF INITIAL PUBLIC OFFERING FIRMS ON BORSA ISTANBUL
}

\author{
BORSA İSTANBUL'DA İLK HALKA ARZI GERÇEKLEŞEN FİRMALARIN BİRLEŞME VE \\ SATIN ALMA AKTIVITELERI
}

DOI:10.17755/esosder.02862

\section{Ŭ̆ur ÇELİKYURT ${ }^{1}$ Banu Nur DÖNMEZ ${ }^{2}$}

\begin{abstract}
This paper studies the mergers and acquisitions (M\&As) activity of initial public offering (IPO) firms on Borsa Istanbul (BIST) that went public between 1990-2014. We find that among the 398 firms that went public 87 firms acquired other firms while 104 firms were targeted by other firms within the first five years after their IPOs. For firms that have been involved in an M\&A activity, the aggregate deal volume corresponds to $16 \%$ of their market size for acquiring IPO firms, and $29 \%$ of their market size for targeted IPO firms. On average, while these IPO firms acquired 2.1 firms within five years, they were targeted by 1.7 firms. As a result, firms that convert to public ownership on BIST might participate as acquiring firms or as target firms in the subsequent M\&A processes in the first five years after their IPO. Our findings indicate that firms go public on BIST mainly to provide an exit opportunity for their existing shareholders, and they accomplish this i) through the sale of existing shares to the general public in an IPO or ii) through the sale of existing shares to the acquiring firms in a post-IPO M\&A.
\end{abstract}

Keywords: Initial Public Offerings, Mergers and Acquisitions, Borsa Istanbul

JEL Classification: G30, G34

$\ddot{O} z$

Bu çalışmada Borsa İstanbul'da 1990-2014 arası ilk halka arzı gerçekleşen firmaların birleşme ve satın alma aktiviteleri incelenmiştir. Halka arz edilen 398 firma arasından 87 firma ilk halka arzlarından sonraki beş yıl içinde başka firma satın almış, 104'ü ise başka firmalar tarafından hedef alınmıștır. Birleşme ve satın alma aktivitesine katılmış firmalar için toplam işlem hacmi halka arz edilip alıcı olan firmaların market değerinin \%16'sına, halka arz edilip hedef olan firmaların market değerinin \%29'una denk gelmektedir. Ortalama olarak, bu halka arz edilen firmalar beş yıl içinde 2.1 firma satın alırken 1.7 firma tarafından da hedef alınmıştır. Sonuç olarak, BIST’te halka arzı gerçekleşen firmalar halka açılmayı takip eden ilk beş yıldaki birleşme ve satın alma süreçlerine alıcı firma ya da hedef firma olarak katılabilmektedir. Bulgularımıza göre firmalar çoğunlukla mevcut hissedarlarına bir çıkış fırsatı sağlamak amaciyla BIST'te halka açılmakta ve bunu i) ilk halka arzda mevcut hisselerin genel halka satışı yoluyla ya da ii) halka arz sonrası birleşme ve satın almalarda mevcut hisselerin alıcı firmaya satışı yoluyla gerçekleştirmektedir.

Anahtar Kelimeler: İlk Halka Arz, Firma Birleşmeleri ve Satın Almaları, Borsa İstanbul

Jel Sinıflandırması: G30, G34

\footnotetext{
${ }^{1}$ Yrd.Doç.Dr., Koç Üniversitesi, İİBF, İşletme Bölümü, ucelikyurt@ku.edu.tr

${ }^{2}$ Lisans Öğrencisi, Koç Üniversitesi, İ̈BF, İşletme Bölümü, bdonmez@ku.edu.tr
} 


\section{Introduction}

An initial public offering (IPO) is a milestone in a firm's life cycle, and therefore the decision to go public is one of the most important high-level corporate decisions to be made in corporations. Because of its importance a large body of corporate finance literature is dedicated to understanding the IPO decision of firms in more detail. In particular, recent studies on IPOs focused more on the motive behind firms' going public decision.

Initial studies on the IPO decision argue that firms go public to facilitate a subsequent sale to another firm, i.e. to become a target, whereas more recent studies argue that firms go public to fund external growth through acquisitions, i.e. to become an acquirer. On the one hand, Zingales (1995) argues that since an IPO sets a market price for the stock of a company, it helps increase the value initial owners can extract from the sale of their company. Therefore, firms go public with a subsequent sale in mind. Similarly, Mello and Parsons (1998) view the IPO as the first step in the complex process of selling the firm. On the other hand, Celikyurt et al. (2010) argue that a firm can use either the primary proceeds raised in its IPO or its publicly traded stock after its IPO as an acquisition currency in subsequent acquisitions. Going public also provides an ongoing access to public debt and equity markets for further acquisition financing. Therefore, firms go public with a subsequent acquisition in mind.

Celikyurt et al. (2010) show that one of the most important motivations behind firms' IPO decision is the need or desire to make acquisitions. They find that IPO firms play a bigger role in the merger and acquisitions (M\&As) by participating as acquirers than they do as targets. ${ }^{3}$ In our study, we explore whether this is also the case for firms traded on Borsa Istanbul (BIST). More specifically, we analyze the M\&A activity of firms going public on BIST. Since firms might be involved in M\&As as acquirers as well as targets after going public, we focus on the role of IPO firms not only as bidders but also as takeover targets in the subsequent M\&A process.

We study the M\&A behavior of newly public firms on BIST within the next five years after their IPO to shed light on the question of whether BIST firms are involved in post-IPO M\&As and if so, whether they mostly become acquirers or targets in these post-IPO M\&A activities.

We find that only $37.4 \%$ of the firms going public on BIST during 1990-2014 participate in M\&As as either acquirers or targets within the five years after their IPO indicating that the majority of IPO firms on BIST are not actively participating in post-IPO M\&As. Moreover, we find that $21.9 \%$ of the IPO firms make at least one acquisition and $26.1 \%$ of them get acquired in total or in part over the five years after the IPO, with the subsamples of acquiring firms and targeted firms not being mutually exclusive. Regardless of whether they are acquirers or targets in the post-IPO M\&A process, IPO firms are most active in the first two years after the IPO year in terms of both the number and the volume of deals they participate in.

Our analysis of the frequency and the volume of post-IPO M\&As for firms which participate in M\&As after their IPO shows that the levels of M\&A activity undertaken by IPO firms on BIST within five years after their IPO are similar for the cases when the IPO firms participate as acquirers or when they participate as takeover targets in the post-IPO M\&A process. Specifically, we find that while IPO firms participate in 2.05 deals as acquirers on

\footnotetext{
${ }^{3}$ Several other studies explore the relation between IPO firms and their subsequent acquisition activity. See, for example, Brau and Fawcett (2006), Hsieh et al. (2011), Brau et al. (2012).
} 
average, they participate in 1.69 deals as targets, with the difference being weakly statistically significant. The total M\&A volume of firms over five years after their IPO, on the other hand, corresponds to $16.17 \%$ of firm size on average for deals when the IPO firm is the acquirer and to $29.37 \%$ for deals when the IPO firm is the target, with the difference not being statistically significant. Overall, our results show that, conditional on being involved in an M\&A deal, acquiring IPO firms and targeted IPO firms are similarly active regarding the frequency and the volume of post-IPO M\&As they participate in.

Finally, our paper also sheds some light on the IPO process of BIST firms by focusing on the types of shares sold in an IPO. Considering the two types of shares that can be sold in an IPO, i.e. primary versus secondary shares, our analysis of the frequency of IPOs and the amount of their proceeds indicates that firms go public on BIST mainly to facilitate the sale of secondary shares by existing shareholders, therefore providing them with an exit opportunity, rather than raise new equity capital for future investments through the sale of primary shares. This result together with our post-IPO M\&A results suggests that firms go public on BIST mainly to provide an exit opportunity for their existing shareholders, either through the sale of secondary shares to the general public in an IPO or through the sale of existing shares to acquiring firms in a postIPO M\&A.

The rest of the paper is organized as follows. Section 2 reviews the related literature. Section 3 describes our IPO sample and presents descriptive statistics. Section 4 analyzes the M\&A activity of IPO firms after going public. Section 5 concludes.

\section{Literature Review}

The literature on IPOs on Borsa Istanbul (called BIST-IPOs hereafter) mainly focuses on the specifics of the IPO process, the IPO underpricing and the IPO long-run performance.

In their descriptive study, Karatepe et al. (2002) document IPOs on BIST during 19902000 and the IPO process itself, and discuss the advantages and disadvantages of going public on BIST. Kılıç et al. (2009) find that costs arising in compliance with capital markets regulations, i.e. the compliance costs, do not constitute an obstacle to companies' going public decision on BIST. Atici and Gursoy (2015) study the ownership structure of non-financial corporations listed on BIST for the period 1992-2014, and find that IPOs contribute to the transformation of ownership structures of these corporations.

Most existing studies about BIST-IPOs show an interest in the pricing of IPO stocks, focusing mainly on the determinants of IPO underpricing such as Dağlı and Kurtaran (2008), Kucukkocaoglu (2008), Cihangir and Kandil (2009), and Ercan and Çevikel (2011). Kiymaz (2000), and Bildik and Yilmaz (2008) analyze both the initial and the aftermarket performance of IPOs and study their determinants. Kaderli and Demir (2008) examine the relation between IPO underpricing and the firm growth subsequent to the IPO and show a weak positive correlation.

Several other studies, on the other hand, analyze the long-run stock performance of IPOs such as Kiymaz (1997), Ewing and Ozfidan (2003), and Erdogan (2010). Durukan (2002) studies the relation between initial returns and long-term returns for IPO firms.

Kurtaran and Er (2008) analyze post-issue operating performance of IPOs and document a general decline in operating performance subsequent to the IPO. Bulut (2008) and Bulut et al. (2009) study the relation between post-issue operating performance of IPO firms and their 
investment bank reputation and auditing firm reputation, respectively, and find no significant correlation between them.

Using a survey analysis, Saraç and Bozkurt (2011) studied the small and medium sized enterprises' tendency to go public and concluded that the low IPO rates are due to these firms' lack of information about going public.

The extent of M\&A activity undertaken by newly public firms on BIST and what role, acquirer or target role, these IPO firms perform in M\&As have not been documented in existing literature. To the best of our knowledge, ours is the first systematic study of the M\&A activity by newly public firms on BIST. Our paper therefore contributes to the literature studying IPO firms on BIST.

\section{Data and Descriptive Statistics}

Borsa Istanbul was founded in December 1985 under the name of Istanbul Stock Exchange. Our IPO data come from BIST database and cover all Turkish IPOs between 19862014. Our sample includes all BIST-IPOs without any size restriction. We obtain M\&A data from Securities Data Company's (SDC) Mergers and Acquisitions database. Since BIST database starts to provide detailed data on IPOs from year 1990 on, relevant M\&A transactions between 1990-2015 are covered in our study. The form of the M\&A deals obtained from SDC include mergers and acquisitions as well as acquisitions of assets and partial stock interest. Firm financial data come from Rasyonet.

\subsection{Frequency and Proceeds of BIST-IPOs}

A total of 453 firms went public on BIST during the 1986-2014 period. ${ }^{4}$ Graph 1 shows the year distribution of the number of IPOs. The number of firms going public shows some variation during the sample period ranging from 1 to 35 . The highest number of IPOs per year is observed in years 1990 and 2000 with 35 IPOs in each year, and the lowest number of IPOs per year is observed in years 2001 and 2009 with only 1 IPO in each year. We observe three periods of low IPO activity on BIST during 1986-2014. The first one covers years 1988-1989 coinciding with a period of high inflation rates. The second downturn in the number of IPOs covers years 2001-2003 and is due to the biggest economic crisis of Turkey in 2001. The third significant downturn in the IPO activity during 2008-2009 is due to the global financial crisis in 2008.

BIST database provides IPO proceeds of firms both in Turkish Liras (TRY) and in US Dollars (USD). Table 1 shows the mean and the median of the total IPO proceeds of firms going public on BIST for each year from 1990 to 2014 and in both currencies. For years 1986-1989, Table 1 shows only the number of IPOs since BIST database provides only the names of firms going public in that time period. In Table 1, we also present inflation adjusted IPO proceeds. Throughout our paper, we report the inflation adjusted values in 2015 currencies for comparability. ${ }^{5}$

In Table 1, we observe a general upward trend in the mean of nominal total proceeds in Turkish Liras from 1990 to 2014 with two clear exceptions in years 2001 and 2009 for which there is only one IPO and we observe a significant decrease in nominal total proceeds from the

\footnotetext{
${ }^{4}$ In our main analysis, we will focus on 398 BIST firms going public in the time period from 1990 to 2014 due to the lack of detailed information on IPOs during 1986-1989.

${ }^{5}$ The inflation rates are obtained from TUIK (Türkiye İstatistik Kurumu - Turkish Statistical Institute).
} 
previous year. The highest mean of nominal total proceeds is 1,186.3 million TRY in 2008, and the lowest mean is 0.05 million TRY in 1992. The mean of inflation adjusted total proceeds is more stable over time showing no clear trend. We observe similar patterns for the median of nominal and inflation adjusted total proceeds.

Table 1 provides the statistics for IPO proceeds of BIST firms in US Dollars as well. As for the Turkish Liras case, we do not observe much fluctuation in inflation adjusted total proceeds for the US Dollars case. Moreover, the nominal total proceeds are also stable over time with no clear trend for the nominal US Dollars case. These observations are valid for both mean and median statistics.

\subsection{Primary versus Secondary Shares}

Firms can sell two types of shares in an IPO: primary shares versus secondary shares. The sale of primary shares represents the sale of new shares to the general public so that the proceeds go to the firm. The sale of secondary shares, on the other hand, simply represents the sale of shares owned by existing shareholders so that the proceeds go to these selling shareholders. Therefore, while new capital is being raised for the firm through the sale of primary shares, no new capital is being raised for the firm through the sale of secondary shares.

Table 2 presents the distribution of IPOs on BIST according to the types of shares sold. For the 55 IPOs in the 1986-1989 period, BIST database only provides firm names, and further details of the IPO process are not available, leaving us with a total of 398 IPOs with available information on the types of shares sold. Among the 398 firms that went public between 19902014, 150 firms made sales of primary shares only, therefore raising new equity capital, comprising $38 \%$ of the IPO sample, whereas 160 of them made sales of secondary shares only, comprising $40 \%$ of the IPO sample. In 82 cases, IPO firms both increased their equity capital and also made sales by shareholders, corresponding to $21 \%$ of all IPOs. ${ }^{6}$

In the early years on BIST, IPOs involved the sale of either primary or secondary shares only. The first year we observe sales of both primary and secondary shares in an IPO is year 1995 with a total of 3 IPO firms selling both types of shares. In earlier years, sale by existing shareholders seems to be the dominating motive behind firms' going public decision on BIST, but as years passed more firms started to prefer selling new shares. Specifically, in years 19901994, the majority of firms preferred sale of secondary shares to sale of primary shares, implying that in this period most firms used the IPO as an exit opportunity for existing shareholders to sell their shares rather than as an opportunity to increase capital for future use in the firm. In years 1995-2000, on the other hand, the majority of firms preferred sale of primary shares to sale of secondary shares, implying that in this period most firms used the IPO to increase capital for future use in the firm. For example, in 1990, 30 firms preferred sale by shareholders and only 2 firms preferred capital increase, whereas in 2000, 5 firms preferred sale by shareholders while 22 firms preferred capital increase. We therefore observe a change in preferences over time for the types of shares sold in an IPO.

The method of selling both primary and secondary shares in an IPO has become more common on BIST since year 2000. In particular, in the last five years of our sample period, firms

\footnotetext{
${ }^{6}$ For the remaining 6 firms that went public after 1989, i.e. for about $1 \%$ of the IPO sample, the details of the IPO process are not provided so that the type of shares that they sell in their IPO is not available.
} 
mainly preferred to issue both types of shares when going public, therefore raising new equity capital while also providing the existing shareholders an opportunity to sell their shares.

Data on the amount of IPO proceeds according to the types of shares sold become available in BIST database starting from 1997 on. In Table 2, we also report the average volume of the total IPO proceeds for each IPO cohort in each year from 1997 to 2014 and the average volume over all sample years. For IPO firms that made sale of primary shares only, the average volume of the primary IPO proceeds is 36.67 million TRY with a range from 5.63 million TRY observed in 2003 to 194.92 million TRY observed in 2007. For IPO firms that made sale of secondary shares only, the average volume of the secondary IPO proceeds is 163.41 million TRY with a range from 0.24 million TRY in 2001 to 938.46 million TRY in 2008. Finally, for IPO firms that raised new equity capital and also made sales by shareholders, the average volume of the total IPO proceeds is 110 million TRY with a range from 12.19 million TRY in 1997 to 636.56 million TRY in 2005.

Overall, our comparison of the average total proceeds raised for the three groups of IPOs in Table 2 shows that the proceeds from IPOs involving sale of primary shares only are much lower than the proceeds from IPOs involving sale of secondary shares only. More specifically, we find that the difference between the means of the volume of IPO proceeds is statistically significant at the $10 \%$ level. Therefore, considering the two types of shares that can be sold in an IPO, i.e. primary versus secondary shares, our analysis of the frequency of IPOs and the amount of their proceeds indicates that firms go public on BIST mainly to facilitate the sale of secondary shares by existing shareholders rather than raise new equity capital for future investments through the sale of primary shares.

\section{BIST-IPO Firms and Their M\&A Activity}

To examine the post-IPO M\&A activity of BIST firms, we study both the frequency and the volume of M\&A deals by BIST-IPO firms during the period from 1990 to 2015. Our analysis is based on a comparison between the M\&A deal activities in cases when the IPO firm is the acquirer and when the IPO firm is the target.

The different forms of the M\&A deals obtained from SDC include mergers and acquisitions as well as acquisitions of assets and acquisitions of partial stock interest, i.e. partial acquisitions. This implies that target firms do not have to be acquired in total in an M\&A process. That is, target firms can also be acquired in part, thus allowing multiple acquisitions of the same target firm during the sample period.

\subsection{Frequency of M\&As after IPO}

\subsubsection{Deals when the IPO firm is acquirer}

We first analyze whether BIST firms acquire other firms in the period after they go public. Graph 2 shows the number of IPO firms involved as acquirers in M\&A deals where year 0 denotes the IPO year. We find that among the 398 IPO firms on BIST from 1990 to 2014, 22 of them make at least one acquisition in their IPO year, corresponding to $5.5 \%$ of the IPO sample. The annual number of firms undertaking acquisitions increases in the first two years after the IPO year and reaches its highest value of 32 in year 2. After that the annual number of IPO firms being acquirers starts to show a decline implying that IPO firms are most active as acquirers within their first two years after IPO. Graph 2 also shows the cumulative number of firms being 
acquirers post-IPO. This number rises each year reaching 87 firms in five years after the IPO showing that $21.9 \%$ of the IPO firms make at least one acquisition over the five years after the IPO. This also implies that approximately 1 out of 5 BIST-IPO firms undertake at least one acquisition in five years after going public.

Graph 3 shows the total number of M\&A deals over time in which the IPO firm is the acquirer, both in annual and cumulative terms. The cumulative number of deals increases over time, starting with only 30 deals in the IPO year and reaching 178 deals in five years. Looking at annual deal counts over time reveals that there is an upward trend over years 0-2 and a downward trend afterwards, verifying our previous finding that IPO firms are most active as acquirers within their first two years after the IPO year.

\subsubsection{Deals when the IPO firm is target}

We also analyze whether BIST firms get acquired by other firms in the period after they go public. Graph 4 shows the number of IPO firms involved as targets in M\&A deals where year 0 denotes the IPO year. We find that among the 398 IPO firms on BIST from 1990 to 2014, 20 of them were involved in at least one M\&A activity as a target firm in their IPO year, corresponding to $5 \%$ of the IPO sample. The annual number of firms being acquired increases in first few years after the IPO year reaching its highest values of 31 and 29 in years 1 and 2, respectively. After that the annual number of IPO firms being targets starts to decline implying that IPO firms are most active as targets within their first two years after IPO. Graph 4 also shows the cumulative number of firms being acquired post-IPO. This number rises each year reaching 104 firms in five years after the IPO showing that $26.1 \%$ of the IPO firms were acquired in total or in part over the five years after the IPO. This also implies that approximately 1 out of 4 BIST-IPO firms are being acquired in five years after going public.

Graph 5 shows the total number of M\&A deals over time in which the IPO firm is the target, both in annual and cumulative terms. The cumulative number of deals increases over time, starting with only 25 deals in the IPO year and reaching 176 deals in five years. Looking at annual deal counts over time reveals that there is an upward trend over years 0-2 and a downward trend afterwards, verifying our previous finding that IPO firms are most active as targets within their first two years after the IPO year.

\subsubsection{Comparison between acquirer and target cases}

Our findings so far indicate that the majority of IPO firms on BIST do not participate in M\&As in the five-year period after going public. We find that only $21.9 \%$ of the IPO firms make an acquisition and only $26.1 \%$ of the IPO firms get acquired over the five years after the IPO. It is important to note that the subsample of acquiring IPO firms and that of targeted IPO firms are not mutually exclusive. That is, there are firms participating in multiple M\&As as either acquirers or targets, and we find that there are 42 such firms. It turns out that a total of 149 firms out of 398 BIST-IPO firms participate in M\&As as either acquirers or targets, comprising $37.4 \%$ of the BIST-IPO universe covering 1990-2014. Overall, our results imply that the majority of firms going public on BIST are reluctant to get engaged in M\&As after their IPOs and therefore they are not actively participating in post-IPO M\&As.

In this section, we explore whether firms traded on BIST participate more as acquirers or as targets in M\&A deals within the first five years after going public. Specifically, we compare the cumulative number of M\&A deals per IPO firm after going public in cases when the IPO firm 
is the acquirer and when the IPO firm is the target. Graphs 6 and 7 show the number of M\&A deals per firm over the years where year 0 denotes the IPO year. In Graph 6, we include all IPO firms with or without an M\&A activity to calculate the number of M\&A deals per firm. In Graph 7 , on the other hand, we include only those IPO firms that participate in at least one M\&A activity to calculate the number of M\&A deals per firm. The deal counts in Graph 6 are much lower than the deal counts in Graph 7 since our calculations in Graph 6 include firms with zero deal count as well, whereas our calculations in Graph 7 exclude those firms with zero deal count and include only firms with at least one deal count.

Graph 6 reveals very similar patterns for the acquirer and the target cases. Specifically, the number of M\&A deals per firm in the IPO year is 0.08 for the acquirer case, corresponding to 30 deals by 398 firms, and 0.06 for the target case, corresponding to 25 deals by 398 firms. In both cases, the M\&A deal counts per firm increase over the years and stay very close to each other, reaching 0.53 and 0.52 for the acquirer case and the target case, respectively. This finding indicates that the amounts of M\&A activity undertaken by IPO firms on BIST are similar for the cases when the IPO firms participate as acquirers or when they participate as takeover targets in the post-IPO M\&A process.

When we calculate the number of M\&A deals per firm for the subsample of IPO firms with at least one M\&A activity, we find that IPO firms are more active as acquirers in that they participate in a higher number of M\&A deals per firm as acquirers than as targets throughout the five-year post-IPO period. Specifically, Graph 7 shows that, conditional on being involved in an M\&A deal in the five-year post-IPO period, the number of M\&A deals per firm in the IPO year is 0.34 for the acquirer case, corresponding to 30 deals by 87 firms, and 0.24 for the target case, corresponding to 25 deals by 104 firms. In both cases, the numbers increase over the years with the acquiring IPO firms participating in more M\&A deals than the targeted IPO firms. On average, while IPO firms participate in 2.05 deals as acquirers in the five years after their IPO, they participate in only 1.69 deals as targets, with the difference being statistically significant at the $10 \%$ level. Overall, our results show that, conditional on being involved in an M\&A deal, acquiring IPO firms are more active than targeted IPO firms regarding the number of deals they participate in.

\subsection{Volume of M\&As after IPO}

Since the majority of BIST firms do not participate in post-IPO M\&As, as a further analysis we focus our attention on those IPO firms that participated in post-IPO M\&A deals, for which the deal volume is available from SDC's Mergers and Acquisitions database.

To find out how large the post-IPO M\&A deals are in comparison to the IPO firm's size, we calculate the volume of these deals as a percentage of firm size measured in the IPO year. We use two alternative measures of firm size, namely total assets (TA) and market value of assets (MVA). ${ }^{7}$ For each IPO firm, we calculate the annual percentage M\&A deal volume as follows:

$$
M \& A \text { volume as a percentage of } T A=\left(\frac{\text { Inflation adjusted deal volume }}{\text { Inflation adjusted } T A \text { at the time of IPO }}\right)
$$

\footnotetext{
${ }^{7}$ Total assets equal the book value of assets. Market value of assets is defined as the book value of assets less the book value of equity plus the equity market capitalization.
} 


$$
M \& A \text { volume as a percentage of } M V A=\left(\frac{\text { Inflation adjusted deal volume }}{\text { Inflation adjusted MVA at the time of IPO }}\right)
$$

We use inflation adjusted dollars so that the deal volume and the firm size are given in the same year's dollars. We also calculate cumulative percentage deal volumes for each firm by adding up the annual inflation adjusted deal volumes for a given time window and then dividing the total by the inflation adjusted firm size measured in the IPO year. The time window extends out to five years after the IPO year, i.e. from year 0 to year 5 where year 0 denotes the IPO year.

\subsubsection{Deals when the IPO firm is acquirer}

Graph 8 shows the average M\&A volume over time as a percentage of total assets measured in the IPO year for BIST-IPO firms which make at least one acquisition within five years after going public. We provide averages of annual deal volumes and also averages of cumulative deal volumes where year 0 denotes the IPO year. We find that, in the IPO year, the M\&A volume averages $1.05 \%$ of firm size. The average annual deal volume becomes $8.20 \%$ of firm size in year 1, and reaches its highest value of $19.53 \%$ in year 2, revealing an upward trend over years 0-2. Afterwards we observe a downward trend in average annual deal volume over years 3-5 reaching its lowest level of $1.39 \%$ in year 5 . Consistently, we observe a sharp rise from $1.05 \%$ to $28.78 \%$ in the average cumulative deal volume over years $0-2$ and then a modest increase over years 3-5 with a mean increase of $1.93 \%$ each year during this period. We find that the total acquisition volume of a typical BIST-IPO firm over five years after going public amounts to $34.57 \%$ of its firm size measured as a percentage of total assets.

Graph 9 shows the average M\&A volume over time as a percentage of market value of assets measured in the IPO year for IPO firms which make at least one acquisition within five years after going public. As in Graph 8, we provide averages of annual deal volumes and also averages of cumulative deal volumes in Graph 9. Since the market value of assets is greater than the value of total assets, deal volumes measured as a percentage of market values are lower than deal volumes measured as a percentage of total assets. We find that, in the IPO year, the M\&A volume averages $0.75 \%$ of firm size. The average annual deal volume becomes $1.74 \%$ of firm size in year 1, and reaches its highest value of $10.13 \%$ in year 2, revealing an upward trend over years $0-2$. Afterwards we observe a downward trend in average annual deal volume over years 35 reaching its lowest level of $1.00 \%$ in year 5 . Consistently, we observe a sharp rise from $0.75 \%$ to $12.62 \%$ in the average cumulative deal volume over years $0-2$ and then a modest increase over years 3-5 with a mean increase of $1.18 \%$ each year during this period. We find that the total acquisition volume of a typical BIST-IPO firm over five years after going public amounts to $16.17 \%$ of its firm size measured as a percentage of market value.

Overall, our analysis of the M\&A volumes in Graphs 8 and 9 verifies our previous finding that IPO firms are most active as acquirers within their first two years after the IPO year.

\subsubsection{Deals when the IPO firm is target}

We also analyze the deal volume of M\&A activities in which BIST firms get acquired by other firms in the five-year period after they go public. As is the case for IPO firms which make acquisitions, we analyze the M\&A volume over time for BIST-IPO firms which become targets at least once in the five years after going public. Graphs 10 and 11 show the M\&A deal volumes as a percentage of total assets and as a percentage of market value of assets, respectively, with 
both firm size measures taken in the IPO year. As before, we provide averages of annual deal volumes and also averages of cumulative deal volumes where year 0 denotes the IPO year.

Graph 10 shows that, in the IPO year, the M\&A volume averages $6.23 \%$ of firm size. The average annual deal volume is $4.58 \%$ of firm size in year 1 , and reaches its highest value of $15.21 \%$ in year 2 , revealing an upward trend over years $0-2$. Afterwards we observe a downward trend in average annual deal volume over years 3-5 reaching its lowest level of 3.50\% in year 5 . Consistently, we observe a sharp rise from $6.23 \%$ to $26.02 \%$ in the average cumulative deal volume over years 0-2 and then a modest increase over years 3-5 with a mean increase of $6.24 \%$ each year during this period. We find that the total deal volume of a typical targeted BIST-IPO firm over five years after going public amounts to $44.75 \%$ of its firm size measured as a percentage of total assets.

Compared to Graph 10 where we use total assets as the firm size, Graph 11 shows a similar pattern of the M\&A volume over time as a percentage of market value of assets, with the percentages being lower due to the larger market value of the firms. We find that, in the IPO year, the M\&A volume averages $4.73 \%$ of firm size. The average annual deal volume is $3.56 \%$ of firm size in year 1, and reaches its highest value of $9.64 \%$ in year 2, revealing an upward trend over years $0-2$. Afterwards we observe a downward trend in average annual deal volume over years 3 5 reaching its lowest level of $1.44 \%$ in year 5 . Consistently, we observe a sharp rise from $4.73 \%$ to $17.93 \%$ in the average cumulative deal volume over years $0-2$ and then a modest increase over years 3-5 with a mean increase of 3.81\% each year during this period. We find that the total deal volume of a typical targeted BIST-IPO firm over five years after going public amounts to $29.37 \%$ of its firm size measured as a percentage of market value.

\subsubsection{Comparison between acquirer and target cases}

So far we find that there is an upward trend in annual M\&A volume over years 0-2, where year 0 denotes the IPO year, and a downward trend afterwards, regardless of whether the BISTIPO firm is the acquirer or the target in the M\&A process. This finding implies that firms which participate in post-IPO M\&A activities are most active within their first two years after IPO in terms of the M\&A deal amount. Our result on M\&A deal volumes complements our previous result on M\&A deal counts indicating that IPO firms are most active in M\&A activity in first two years after going public.

Table 3 presents the mean cumulative M\&A volume as a percentage of firm size for the subsample of acquiring IPO firms and the subsample of targeted IPO firms. In Panel A we use total assets and in Panel B we use market value of assets as the measure of firm size. Due to higher market values, the percentage deal volumes are lower in Panel B. The mean cumulative deal volumes are increasing over time since these cumulative deal volumes are found for each firm by adding up the annual deal volumes for a given time window and then dividing the total by the firm size measured in the IPO year. Table 3 also reports the t-statistics to determine whether the mean cumulative deal volumes are equal for the two IPO firm subsamples, namely the acquirer and the target subsamples.

Panel A of Table 3 shows that the mean M\&A volume of firms in their IPO year is $1.05 \%$ of firm size at the time of the IPO for deals when the IPO firm is the acquirer and is $6.23 \%$ for deals when the IPO firm is the target. The t-test shows that these deal volumes in the IPO year are significantly different from each other at the 5\% level. The difference, however, disappears after the IPO year and loses its statistical significance over time, and we observe similar percentage 
deal volumes for the acquirer and the target subsamples. We find that, on average, the total M\&A volume of IPO firms over the five-year period corresponds to $34.57 \%$ of firm size at the time of the IPO for deals when the IPO firm is the acquirer and to $44.75 \%$ for deals when the IPO firm is the target, with these means, however, not being significantly different from each other.

Panel B of Table 3 shows that the mean M\&A volume of firms in their IPO year is $0.75 \%$ of firm size at the time of the IPO for deals when the IPO firm is the acquirer and is $4.73 \%$ for deals when the IPO firm is the target. The t-test shows that these deal volumes in the IPO year are significantly different from each other at the $10 \%$ level. The cumulative deal volumes remain significantly different from each other at the 5\% level over the years $0-1$. The difference then disappears and loses its statistical significance over time. We find that, on average, the total M\&A volume of IPO firms over the five-year period corresponds to $16.17 \%$ of firm size at the time of the IPO for deals when the IPO firm is the acquirer and to $29.37 \%$ for deals when the IPO firm is the target, with these means, however, not being significantly different from each other.

Our results on the post-IPO M\&A activity provide some support for our results on the types of shares sold in an IPO regarding the motive for going public. Specifically, we find that firms which go public on BIST mainly sell shares of their existing shareholders in an IPO, therefore providing them with an exit opportunity, and do not raise new equity capital for future investments such as post-IPO acquisitions. Our finding that these BIST firms have a larger total deal volume as a percentage of their firm size when they are targets in post-IPO M\&As rather than acquirers once again points to more of an exit opportunity for existing shareholders than a growth opportunity through acquisitions. In other words, BIST-IPO firms prefer to sell their existing shares to the acquiring firms in post-IPO M\&As rather than buy shares of other target firms. Therefore, our results are consistent with those for Swedish IPOs in Rydqvist and Högholm (1995) and those for Italian IPOs in Pagano et al. (1998) who show that going public is a decision made by controlling shareholders who eventually want to sell out.

\section{Conclusion}

We study the mergers and acquisitions activity within five years after the initial public offering for firms going public on Borsa Istanbul and analyze the role of these IPO firms not only as bidders but also as takeover targets in the post-IPO M\&A process.

We show that $37.4 \%$ of the firms participate in M\&As as either acquirers or targets indicating that the majority of IPO firms on BIST are not actively participating in post-IPO M\&As. Those IPO firms which are involved in post-IPO M\&A activity are most active in the first two years after the IPO year, regardless of whether they are acquirers or targets, in terms of both the number and the volume of deals they participate in. Moreover, the levels of M\&A activity undertaken by IPO firms are similar for the cases when they participate as acquirers or when they participate as takeover targets in the post-IPO M\&A process. Specifically, while the number of post-IPO deals per firm over five years is slightly higher for acquiring IPO firms than for target IPO firms, the total deal volume over five years as a percentage of firm size is higher for target IPO firms than for acquiring IPO firms, the difference however not being statistically significant.

Our analysis of the frequency of IPOs and the amount of their proceeds shows that firms go public on BIST mainly to facilitate the sale of secondary shares by existing shareholders, therefore providing them with an exit opportunity, rather than raise new equity capital through the sale of primary shares for future investments such as acquisitions. 
Overall, our results suggest that firms go public on BIST mainly to provide an exit opportunity for their existing shareholders, either through the sale of secondary shares to the general public in an IPO or through the sale of existing shares to acquiring firms in a post-IPO M\&A. Finally, the low participation of BIST firms in post-IPO M\&A activity also implies that the majority of firms on BIST do not grow through acquisitions in the five-year period after they go public.

\section{REFERENCES}

Atici, Gonca, and Guner Gursoy. 2015. "Changing Ownership in the Turkish Non-Financial Corporations Listed on Borsa Istanbul (BIST)" Corporate Ownership \& Control 13: 1062-1072.

Bildik, Recep, and Mustafa K. Y1lmaz. 2008. "The Market Performance of Initial Public Offerings in the Istanbul Stock Exchange" BDDK Bankacılık ve Finansal Piyasalar 2: 49 75 .

Brau, James C., and Stanley E. Fawcett. 2006. "Initial public offerings: an analysis of theory and practice.” Journal of Finance 61: 399-436.

Brau, James C., Robert B. Couch, and Ninon K. Sutton. 2012. "The desire to acquire and IPO long-run underperformance." Journal of Financial and Quantitative Analysis 47: 493-510.

Bulut, Halil İbrahim. 2008. "Investment Bank Reputation and the Post-IPO Operating Performance: The Case of the Istanbul Stock Exchange" The ISE Review Vol:10 No:39, 17-40.

Bulut, Halil Ibrahim, Fikret Cankaya, and Bünyamin Er. 2009. "Auditing firm reputation and the post-issue operating performance in an emerging market: evidence from Turkish IPO firms" Investment Management and Financial Innovations 6: 212-229.

Celikyurt, Ugur, Merih Sevilir, and Anil Shivdasani. 2010. "Going public to acquire? The acquisition motive in IPOs" Journal of Financial Economics 96: 345-363.

Cihangir, Mehmet, and İlkut Elif Kandil. 2009. "Türkiye'de Borsaya Yeni Kote İşletmelerin Halka İlk Arzda Uyguladıkları Düşük Fiyatlandırma Olgusunun Test Edilmesi ve Nedenleri Üzerine Bir Değerlendirme” Muhasebe ve Finansman Dergisi 44: 165-178.

Dağl1, Hüseyin, and Ahmet Kurtaran. 2008. "İlk Halka Arzlarda Düşük Fiyatlandırmayı Etkileyen Unsurlar: Türkiye Örneği” Muhasebe ve Finansman Dergisi 39: 58-66.

Durukan, M. Banu. 2002. "The Relationship Between IPO Returns and Factors Influencing IPO Performance: Case of Istanbul Stock Exchange” Managerial Finance 28: 18-38.

Ercan, Metin, and Serhat Çevikel. 2011. "Survey on IPO underpricing in the Istanbul Stock Exchange" İktisat İşletme ve Finans 26: 85-117.

Erdogan, Aysa Ipek. 2010. "The Long-Run Performance of Initial Public Offerings: The Case of Turkey" European Journal of Economics, Finance and Administrative Sciences 26: 5764.

Ewing, Bradley T., and Ozkan Ozfidan. 2003. "The Performance of Initial Public Offerings in an Emerging Market: The Case of the Istanbul Stock Exchange" International Journal of Business 8(2): 150-167. 
Hsieh, Jim, Evgeny Lyandres, and Alexei Zhdanov. 2011. "A Theory of Merger-Driven IPOs" Journal of Financial and Quantitative Analysis 46: 1367-1405.

Kaderli, Yusuf, and Sezgin Demir. 2008. "Düşük Fiyatlandırılmış Halka Arz Firma Kalitesinin Bir Göstergesi mi?" Muhasebe ve Finansman Dergisi 37: 107-115.

Karatepe, Yalçın, Elif Karaaslan, and Fazıl Gökgöz. 2002. “Türkiye'de Birincil Halka Arz Uygulamalarının Analizi” İktisat İşletme ve Finans 17: 20-31.

K1lıç, Saim, Ali Alp, and Önder Kaymaz. 2009. “Are Compliance Costs Arising From Capital Markets Regulations in Turkey Actually That High to Hinder IPOs?" The ISE Review Vol:11 No:41, 1-24.

Kiymaz, Halil. 1997. "The Long Run Performances of Turkish Industrial IPOs: 1990-1995 Experience" The ISE Review Vol:1 No:3, 43-67.

Kiymaz, Halil. 2000. "The initial and aftermarket performance of IPOs in an emerging market: evidence from Istanbul stock exchange" Journal of Multinational Financial Management 10: 213-227.

Kucukkocaoglu, Guray. 2008. "Underpricing in Turkey: A Comparison of the IPO Methods" International Research Journal of Finance and Economics 13: 162-182.

Kurtaran, Ahmet, and Bünyamin Er. 2008. "The post-issue operating performance of IPOs in an emerging market: evidence from Istanbul Stock Exchange” Investment Management and Financial Innovations 5: 50-62.

Mello, Antonio S., and John E. Parsons. 1998. "Going public and the ownership structure of the firm" Journal of Financial Economics 49: 79-109.

Pagano, Marco, Fabio Panetta, and Luigi Zingales. 1998. "Why Do Companies Go Public? An Empirical Analysis” Journal of Finance 53: 27-64.

Rydqvist, Kristian, and Kenneth Högholm. 1995. "Going public in the 1980s: Evidence from Sweden” European Financial Management 1: 287-315.

Saraç, Mehmet, and İbrahim Bozkurt. 2011. “KOBİ'lerin Halka Açılma Eğilimleri ve Gelişen İşletmeler Piyasası'nın KOBİ'lerin Halka Açılma İstekleri Üzerine Etkisi” Muhasebe ve Finansman Dergisi 49: 89-98.

Zingales, L. 1995. Insider Ownership and the Decision to Go Public. Review of Economic Studies 62: 425-448. 
Table 1: Summary statistics for IPO proceeds of firms going public on BIST during 1986-2014

\begin{tabular}{|c|c|c|c|c|c|c|c|c|c|c|c|c|}
\hline \multirow[b]{3}{*}{ Year } & \multirow[b]{3}{*}{ \# of IPOS } & \multicolumn{4}{|c|}{ Turkish Lira (TRY) } & \multicolumn{7}{|c|}{ US Dollars (USD) } \\
\hline & & \multicolumn{2}{|c|}{ Nominal } & \multicolumn{2}{|c|}{ Inflation Adjusted (as of 2015) } & \multicolumn{3}{|c|}{ Nominal } & \multicolumn{4}{|c|}{ Inflation Adjusted (as of 2015) } \\
\hline & & Mean & Median & Mean & Median & Mean & & Median & & Mean & & Median \\
\hline 1986 & 18 & & & & & & & & & & & \\
\hline 1987 & 26 & & & & & & & & & & & \\
\hline 1988 & 5 & & & & & & & & & & & \\
\hline 1989 & 6 & & & & & & & & & & & \\
\hline 1990 & 35 & $77,010.91 €$ & $32,745.00 €$ & $130,320,808.38 €$ & $55,412,343.36 €$ & $\$ 29,293,646.31$ & $\$$ & $12,058,309.87$ & $\$$ & $53,121,838.40$ & $\$$ & $21,866,843.80$ \\
\hline 1991 & 23 & $61,533.03 €$ & $25,335.73 も$ & $60,858,297.72 も$ & $25,057,913.18 €$ & $\$ 16,317,792.18$ & $\$$ & $6,644,744.92$ & $\$$ & $28,384,745.00$ & $\$$ & $11,558,511.60$ \\
\hline 1992 & 13 & $49,516.81 も$ & $32,812.50 €$ & $29,502,316.19 €$ & $19,549,819.19 も$ & $\$ 7,263,349.99$ & $\$$ & $6,006,260.24$ & $\$$ & $12,263,004.03$ & $\$$ & $10,140,609.17$ \\
\hline 1993 & 16 & $111,516.50 €$ & $77,900.00 €$ & $38,832,249.13 も$ & $27,126,319.49 も$ & $\$ 9,527,917.44$ & $\$$ & $7,172,148.07$ & $\$$ & $15,623,896.40$ & $\$$ & $11,760,901.50$ \\
\hline 1994 & 25 & $307,346.60$ も & $243,000.00$ も & $47,460,824.91$ も & $37,524,346.89 も$ & $\$ 10,819,200.98$ & $\$$ & $8,383,420.90$ & $\$$ & $17,290,074.57$ & $\$$ & $13,397,474.80$ \\
\hline 1995 & 29 & $368,911.45$ も & $240,000.00$ も & $32,368,035.02 \ddagger$ & $21,057,433.72 €$ & $\$ 8,509,741.88$ & $\$$ & $5,815,362.25$ & $\$$ & $13,227,650.33$ & $\$$ & $9,039,472.58$ \\
\hline 1996 & 27 & $544,473.92 も$ & $317,483.67$ も & $26,569,390.51 も$ & $15,492,657.03 も$ & $\$ \quad 6,219,319.10$ & $\$$ & $4,053,983.59$ & $\$$ & $9,392,196.84$ & $\$$ & $6,122,183.36$ \\
\hline 1997 & 29 & $2,213,333.46 も$ & $976,250.00 €$ & $54,247,546.79 も$ & $23,927,333.35 €$ & $\$ 14,495,743.65$ & $\$$ & $7,443,408.79$ & $\$$ & $21,390,425.98$ & $\$$ & $10,983,754.17$ \\
\hline 1998 & 20 & $4,715,914.34 €$ & $1,415,000.00 €$ & $68,111,009.74 €$ & $20,436,562.64 €$ & $\$ 19,167,420.04$ & $\$$ & $5,694,928.09$ & $\$$ & $27,852,402.70$ & $\$$ & $8,275,366.75$ \\
\hline 1999 & 10 & $4,647,293.28 も$ & $1,853,500.00 €$ & $39,762,991.43 も$ & $15,858,845.17$ も & $\$ 9,072,236.62$ & $\$$ & $3,441,968.43$ & $\$$ & $12,900,453.43$ & $\$$ & $4,894,377.79$ \\
\hline 2000 & 35 & $49,160,628.55 も$ & $10,810,000.00 €$ & $302,608,829.34 €$ & $66,541,082.60 €$ & $\$ 80,177,781.11$ & $\$$ & $17,232,748.92$ & $\$$ & $110,282,883.23$ & $\$$ & $23,703,290.49$ \\
\hline 2001 & 1 & $385,875.00 €$ & $385,875.00 €$ & $1,409,397.80 €$ & 1,409,397.80も & $\$ \quad 242,654.49$ & $\$$ & $242,654.49$ & $\$$ & $324,580.62$ & $\$$ & $324,580.62$ \\
\hline 2002 & 4 & $19,154,612.50 も$ & $22,065,625.00 €$ & $53,920,380.93 €$ & $62,114,903.42 €$ & $\$ 14,116,839.61$ & $\$$ & $16,400,924.36$ & $\$$ & $18,587,490.64$ & $\$$ & $21,594,920.42$ \\
\hline 2003 & 2 & $9,197,671.25 も$ & $9,197,671.25 も$ & $21,875,223.92 も$ & $21,875,223.92 も$ & $\$ \quad 5,626,136.35$ & $\$$ & $5,626,136.35$ & $\$$ & $7,243,446.89$ & $\$$ & $7,243,446.89$ \\
\hline 2004 & 12 & $59,494,670.27$ も & $23,664,061.63 も$ & $129,435,398.02 €$ & $51,483,052.56 も$ & $\$ 40,214,598.72$ & $\$$ & $16,099,010.00$ & $\$$ & $50,423,490.52$ & $\$$ & $20,185,910.19$ \\
\hline 2005 & 9 & $262,450,341.78 も$ & $32,812,500.00 €$ & $530,060,936.53 €$ & $66,270,153.67$ & $\$ 214,924,580.70$ & $\$$ & $24,567,610.06$ & $\$$ & $260,649,393.86$ & $\$$ & $29,794,324.37$ \\
\hline 2006 & 15 & $82,643,464.53 も$ & $9,000,000.00 €$ & $152,222,389.87$ も & $16,577,251.65 も$ & $\$ 62,033,434.93$ & $\$$ & $5,785,920.93$ & $\$$ & $72,869,948.90$ & $\$$ & $6,796,653.49$ \\
\hline 2007 & 9 & $484,895,442.44 €$ & $227,322,072.80 €$ & $824,003,216.11 も$ & $386,297,957.63 €$ & $\$ 366,478,574.46$ & & $173,395,936.54$ & $\$$ & $418,568,872.94$ & & $198,041,977.86$ \\
\hline 2008 & 2 & $1,186,318,920.67 €$ & $1,186,318,920.67 €$ & $1,831,693,284.44 €$ & $1,831,693,284.44 €$ & $\$ 938,460,080.25$ & & $938,460,080.25$ & & $032,113,935.63$ & & $032,113,935.63$ \\
\hline 2009 & 1 & $10,240,000.00 €$ & $10,240,000.00 €$ & $14,841,552.26 も$ & $14,841,552.26 も$ & $\$ \quad 6,908,183.23$ & $\$$ & $6,908,183.23$ & $\$$ & $7,623,507.00$ & $\$$ & $7,623,507.00$ \\
\hline 2010 & 22 & $141,347,599.11 も$ & $56,168,875.00 €$ & $192,542,309.70 も$ & $76,512,689.24 €$ & $\$ 95,637,170.03$ & $\$$ & $38,353,470.02$ & $\$$ & $103,837,211.24$ & $\$$ & $41,641,940.75$ \\
\hline 2011 & 25 & $52,123,080.02 €$ & $21,243,359.00 €$ & $64,283,881.48$ も & $26,199,633.09 も$ & $\$ 33,059,539.89$ & $\$$ & $13,395,522.00$ & $\$$ & $34,794,593.78$ & $\$$ & $14,098,555.16$ \\
\hline 2012 & 16 & $33,221,843.75 €$ & $14,807,250.00 €$ & $38,595,337.44 €$ & $17,202,260.50 €$ & $\$ 18,567,749.47$ & $\$$ & $8,163,468.20$ & $\$$ & $19,145,914.65$ & $\$$ & $8,417,663.41$ \\
\hline 2013 & 9 & $145,494,011.11 も$ & $76,762,500.00 €$ & $157,380,871.82 も$ & $83,033,996.25 も$ & $\$ 80,183,610.58$ & $\$$ & $38,585,365.85$ & $\$$ & $81,482,585.07$ & $\$$ & $39,210,448.78$ \\
\hline 2014 & 9 & $76,706,150.67$ も & $26,000,000.00 €$ & $76,706,150.67$ も & $26,000,000.00 €$ & $\$ 34,318,591.81$ & $\$$ & $12,354,478.50$ & $\$$ & $34,318,591.81$ & $\$$ & $12,354,478.50$ \\
\hline Avg/Sum & 453 & $105,037,246.48$ も & $69,280,509.49 も$ & $196,784,505.21 も$ & $120,379,840.52 も$ & $\$ 84,865,435.75$ & $\$$ & $55,291,441.79$ & $\$$ & $98,548,525.38$ & $\$$ & $62,847,405.16$ \\
\hline
\end{tabular}


Table 2: Distribution of BIST-IPOs during 1990-2014 according to the types of shares sold

\begin{tabular}{|c|c|c|c|c|c|c|c|c|c|c|c|c|c|}
\hline \multirow[b]{2}{*}{ Year } & \multirow[b]{2}{*}{ \# of IPOs } & \multicolumn{4}{|c|}{$\begin{array}{c}\text { Sale of primary shares only } \\
\text { (Capital increase) }\end{array}$} & \multicolumn{4}{|c|}{$\begin{array}{l}\text { Sale of secondary shares only } \\
\text { (Sale by shareholders) }\end{array}$} & \multicolumn{4}{|c|}{ Sale of both primary and secondary shares } \\
\hline & & \# of IPOs & $\begin{array}{l}\text { Percentage } \\
\text { of IPOs }\end{array}$ & & $\begin{array}{l}\text { Average Total } \\
\text { Proceeds }\end{array}$ & \# of IPOs & $\begin{array}{l}\text { Percentage } \\
\text { of IPOs }\end{array}$ & & $\begin{array}{l}\text { Average Total } \\
\text { Proceeds }\end{array}$ & \# of IPOs & $\begin{array}{l}\text { Percentage } \\
\text { of IPOs }\end{array}$ & & $\begin{array}{l}\text { Average Total } \\
\text { Proceeds }\end{array}$ \\
\hline 1990 & 35 & 2 & $6 \%$ & & & 30 & $86 \%$ & & & & & & \\
\hline 1991 & 23 & 3 & $13 \%$ & & & 19 & $83 \%$ & & & & & & \\
\hline 1992 & 13 & 4 & $31 \%$ & & & 9 & $69 \%$ & & & & & & \\
\hline 1993 & 16 & 4 & $25 \%$ & & & 12 & $75 \%$ & & & & & & \\
\hline 1994 & 25 & 8 & $32 \%$ & & & 17 & $68 \%$ & & & & & & \\
\hline 1995 & 29 & 13 & $45 \%$ & & & 11 & $38 \%$ & & & 3 & $10 \%$ & & \\
\hline 1996 & 27 & 13 & $48 \%$ & & & 11 & $41 \%$ & & & 3 & $11 \%$ & & \\
\hline 1997 & 29 & 19 & $66 \%$ & $\$$ & $16,260,410.73$ & 5 & $17 \%$ & $\$$ & $10,092,953.68$ & 5 & $17 \%$ & $\$$ & $12,192,798.71$ \\
\hline 1998 & 20 & 13 & $65 \%$ & $\$$ & $6,223,718.81$ & 1 & $5 \%$ & $\$$ & $1,565,643.15$ & 6 & $30 \%$ & $\$$ & $50,145,735.51$ \\
\hline 1999 & 10 & 5 & $50 \%$ & $\$$ & $6,079,609.90$ & 4 & $40 \%$ & $\$$ & $839,901.18$ & 1 & $10 \%$ & $\$$ & $56,964,710.94$ \\
\hline 2000 & 35 & 22 & $63 \%$ & $\$$ & $22,642,330.97$ & 5 & $14 \%$ & $\$$ & $402,131,015.13$ & 8 & $23 \%$ & $\$$ & $37,179,497.75$ \\
\hline 2001 & 1 & & & & & 1 & $100 \%$ & $\$$ & $242,654.49$ & & & & \\
\hline 2002 & 4 & 2 & $50 \%$ & $\$$ & $8,265,934.54$ & 2 & $50 \%$ & $\$$ & $19,967,744.67$ & & & & \\
\hline 2003 & 2 & 2 & $100 \%$ & $\$$ & $5,626,136.35$ & & & & & & & & \\
\hline 2004 & 12 & 3 & $25 \%$ & $\$$ & $6,600,423.04$ & 3 & $25 \%$ & $\$$ & $87,994,198.20$ & 6 & $50 \%$ & $\$$ & $33,131,886.85$ \\
\hline 2005 & 9 & 2 & $22 \%$ & $\$$ & $13,934,951.00$ & 5 & $56 \%$ & $\$$ & $88,593,045.55$ & 2 & $22 \%$ & $\$$ & $636,564,563.19$ \\
\hline 2006 & 15 & 3 & $20 \%$ & $\$$ & $7,889,268.53$ & 7 & $47 \%$ & $\$$ & $46,645,491.45$ & 5 & $33 \%$ & $\$$ & $115,489,060.61$ \\
\hline 2007 & 9 & 2 & $22 \%$ & $\$$ & $194,923,417.47$ & 3 & $33 \%$ & $\$$ & $615,915,027.09$ & 4 & $44 \%$ & $\$$ & $265,178,813.59$ \\
\hline 2008 & 2 & & & & & 2 & $100 \%$ & $\$$ & $938,460,080.25$ & & & & \\
\hline 2009 & 1 & 1 & $100 \%$ & $\$$ & $6,908,183.23$ & & & & & & & & \\
\hline 2010 & 22 & 5 & $23 \%$ & $\$$ & $172,353,246.57$ & 6 & $27 \%$ & $\$$ & $88,161,143.62$ & 11 & $50 \%$ & $\$$ & $64,844,058.75$ \\
\hline 2011 & 25 & 11 & $44 \%$ & $\$$ & $14,500,011.65$ & 2 & $8 \%$ & $\$$ & $127,807,347.90$ & 12 & $48 \%$ & $\$$ & $34,382,739.52$ \\
\hline 2012 & 16 & 9 & $56 \%$ & $\$$ & $10,216,858.90$ & 1 & $6 \%$ & $\$$ & $54,821,618.00$ & 6 & $38 \%$ & $\$$ & $25,051,773.76$ \\
\hline 2013 & 9 & 2 & $22 \%$ & $\$$ & $87,414,338.55$ & 1 & $11 \%$ & $\$$ & $55,729,706.15$ & 6 & $67 \%$ & $\$$ & $81,849,018.83$ \\
\hline 2014 & 9 & 2 & $22 \%$ & $\$$ & $6,890,264.84$ & 3 & $33 \%$ & $\$$ & $75,655,750.19$ & 4 & $44 \%$ & $\$$ & $17,029,886.50$ \\
\hline Sum/Avg & 398 & 150 & $38 \%$ & $\$$ & $36,670,569.07$ & 160 & $40 \%$ & $\$$ & $163,413,957.54$ & 82 & $21 \%$ & $\$$ & $110,000,349.58$ \\
\hline
\end{tabular}


Table 3: This table presents the cumulative $M \& A$ volumes as a percentage of firm size (total assets or market value of assets in IPO year) in cases when the BIST-IPO firm is the acquirer or the target.

** and $*$ indicate statistical significance at the $5 \%$ and $10 \%$ level, respectively.

\begin{tabular}{|l|c|c|c|c|c|c|c|}
\hline & Year 0 & Years 0-1 & Years 0-2 & Years 0-3 & Years 0-4 & Years 0-5 \\
\hline \multicolumn{7}{|c|}{ Panel A: Cumulative M\&A volume as a percentage of total assets } \\
\hline IPO firm is the acquirer & $1.05 \%$ & $9.25 \%$ & $28.78 \%$ & $31.72 \%$ & $33.18 \%$ & $34.57 \%$ \\
\hline IPO firm is the target & $6.23 \%$ & $10.81 \%$ & $26.02 \%$ & $34.94 \%$ & $41.25 \%$ & $44.75 \%$ \\
\hline t-statistic & $1.99^{* *}$ & 0.20 & -0.15 & 0.17 & 0.41 & 0.52 \\
\hline \multicolumn{1}{|c|}{ Panel B: Cumulative M\&A volume as a percentage of market value of assets } \\
\hline IPO firm is the acquirer & $0.75 \%$ & $2.49 \%$ & $12.62 \%$ & $14.01 \%$ & $15.17 \%$ & $16.17 \%$ \\
\hline IPO firm is the target & $4.73 \%$ & $8.29 \%$ & $17.93 \%$ & $22.81 \%$ & $27.93 \%$ & $29.37 \%$ \\
\hline t-statistic & $1.96 *$ & $2.24 *$ & 0.62 & 0.99 & 1.34 & 1.40 \\
\hline
\end{tabular}

Graph 1

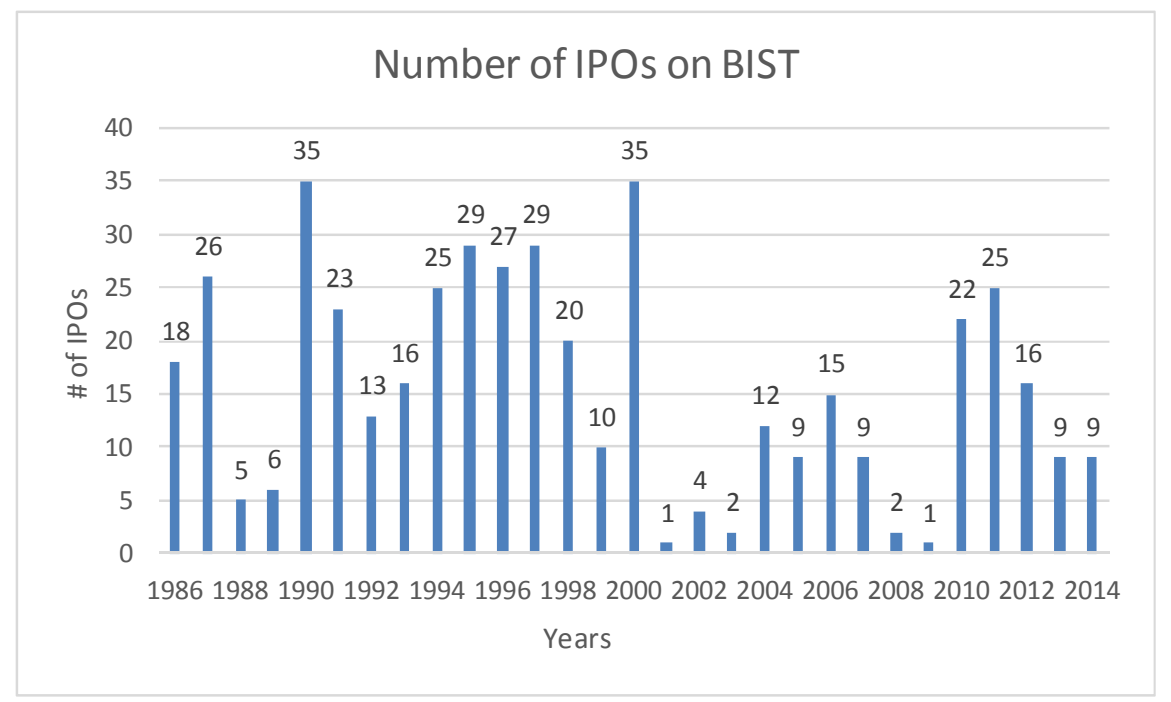




\section{Graph 2}

Number of IPO firms involved as acquirer in M\&A deals

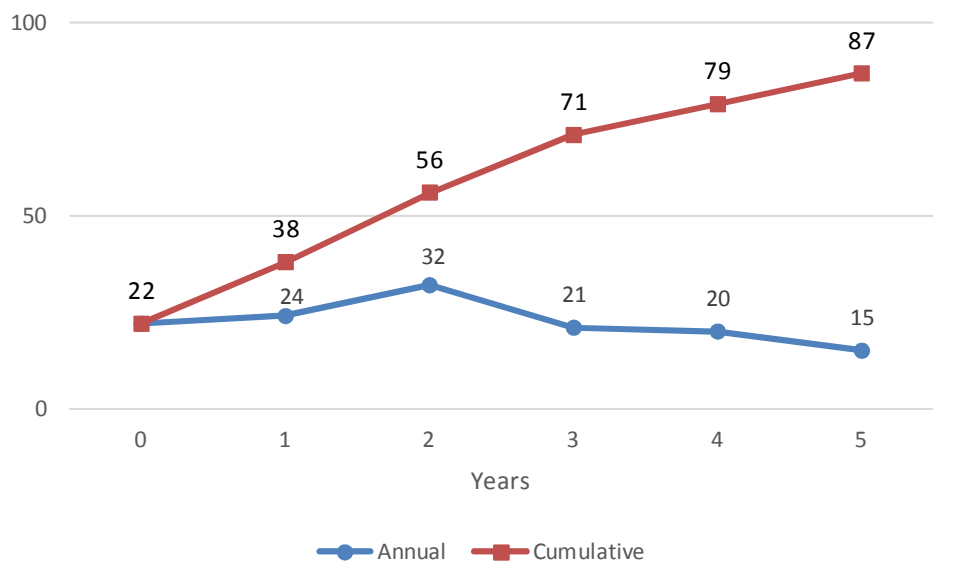

\section{Graph 3}

Number of M\&A deals where IPO firm is the acquirer

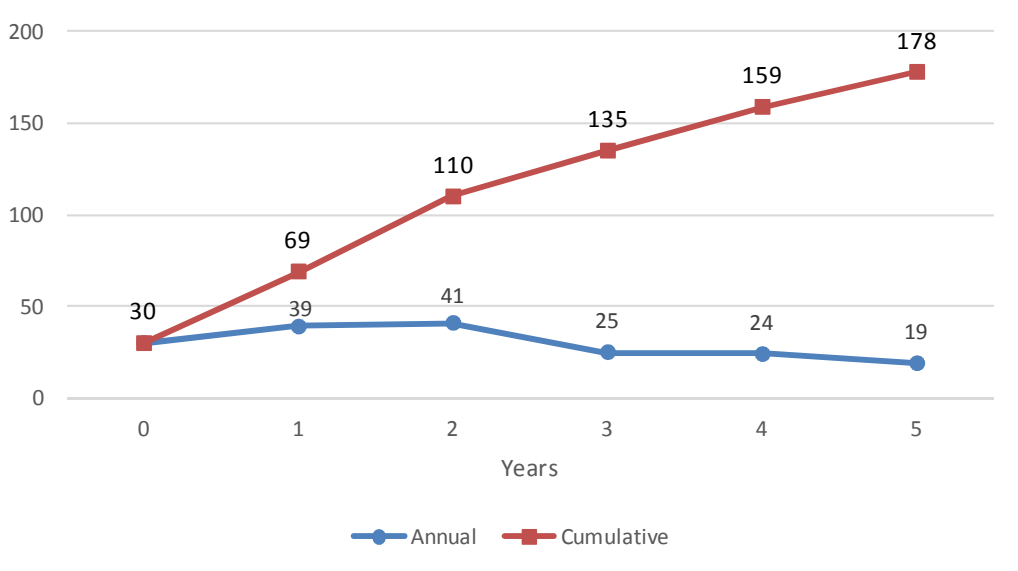

Graph 4

Number of IPO firms involved as target in M\&A deals

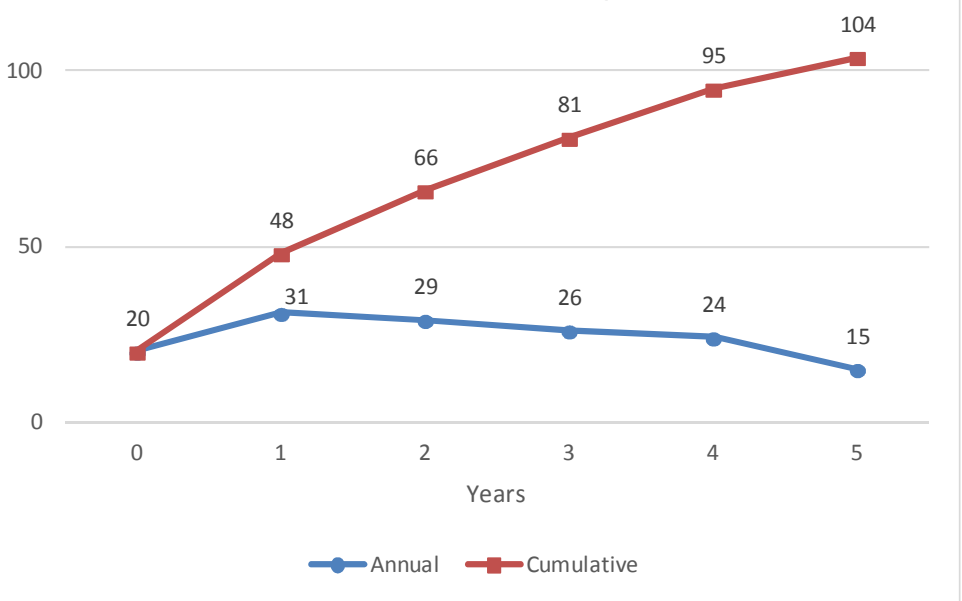

Graph 5

umber of M\&A deals where IPO firm is the target

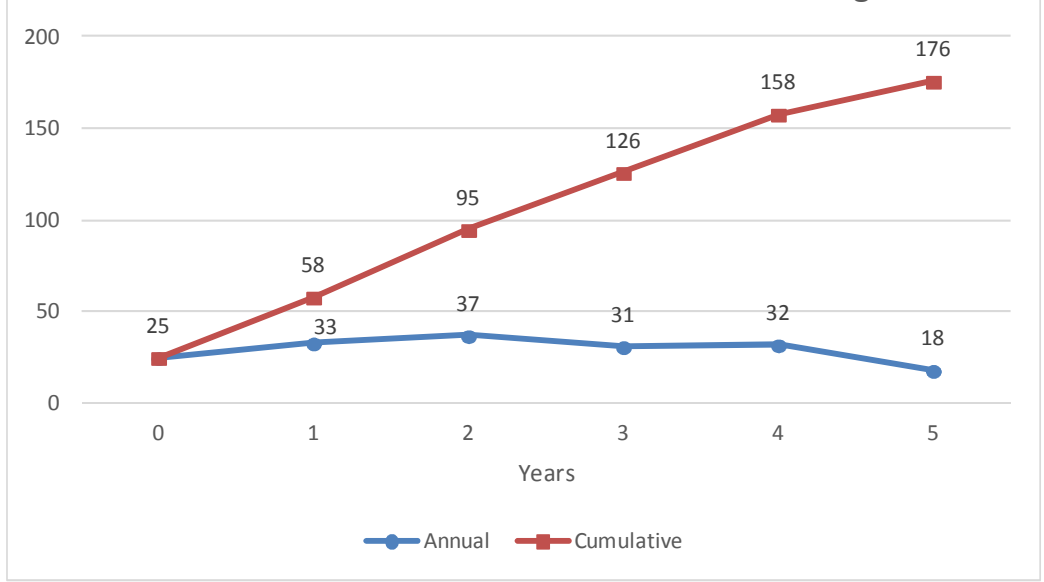




\section{Graph 6}

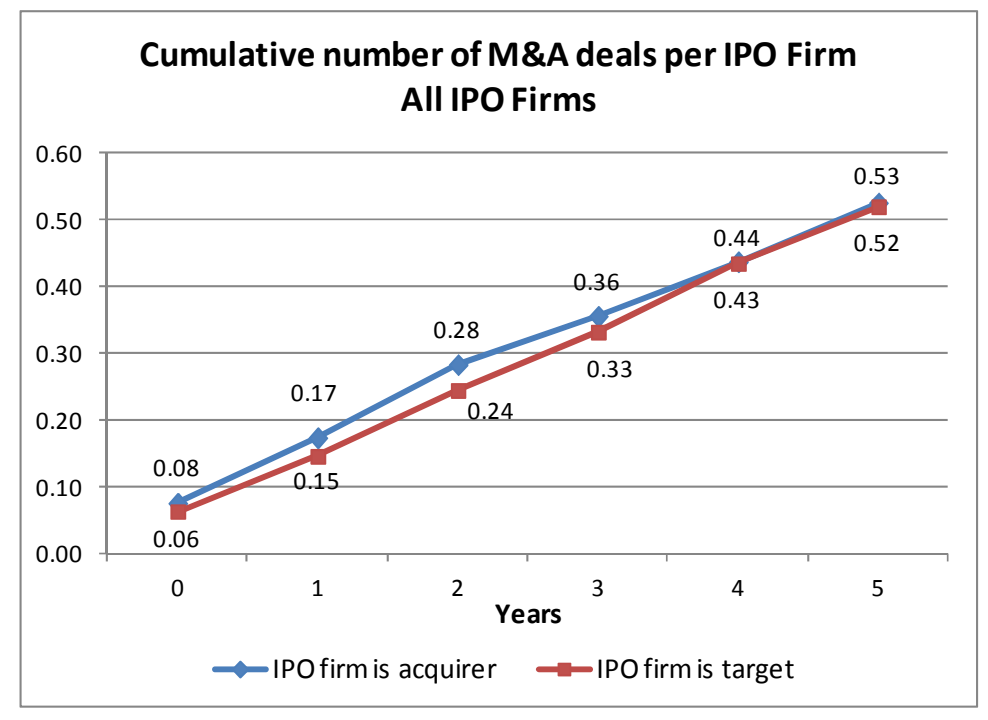

Graph 7

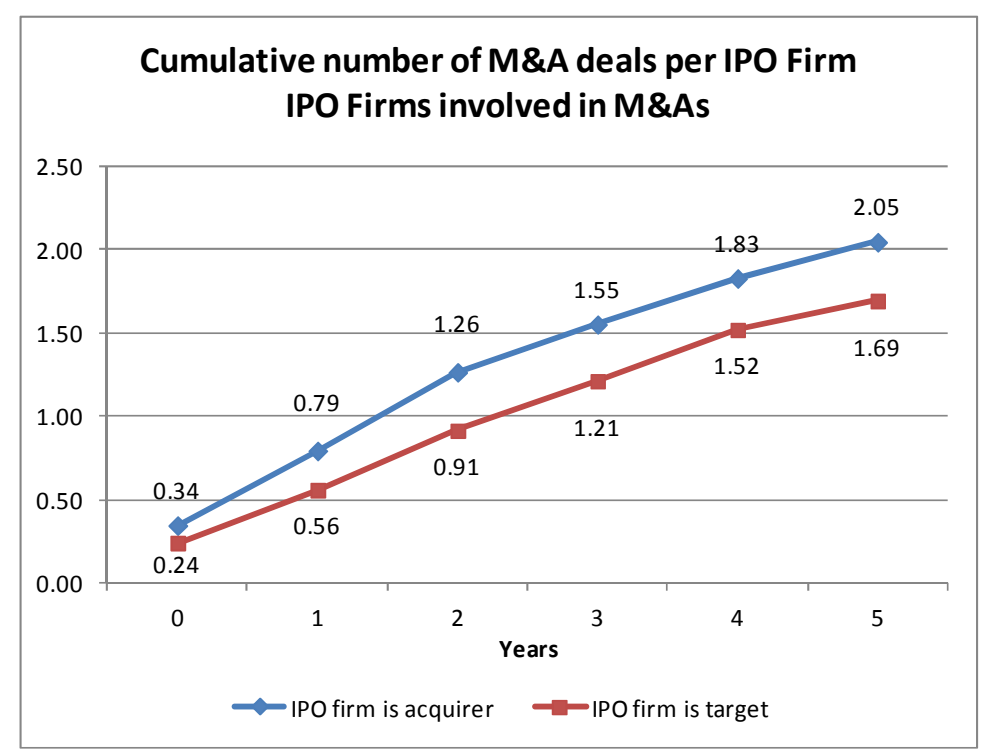

Graph 8

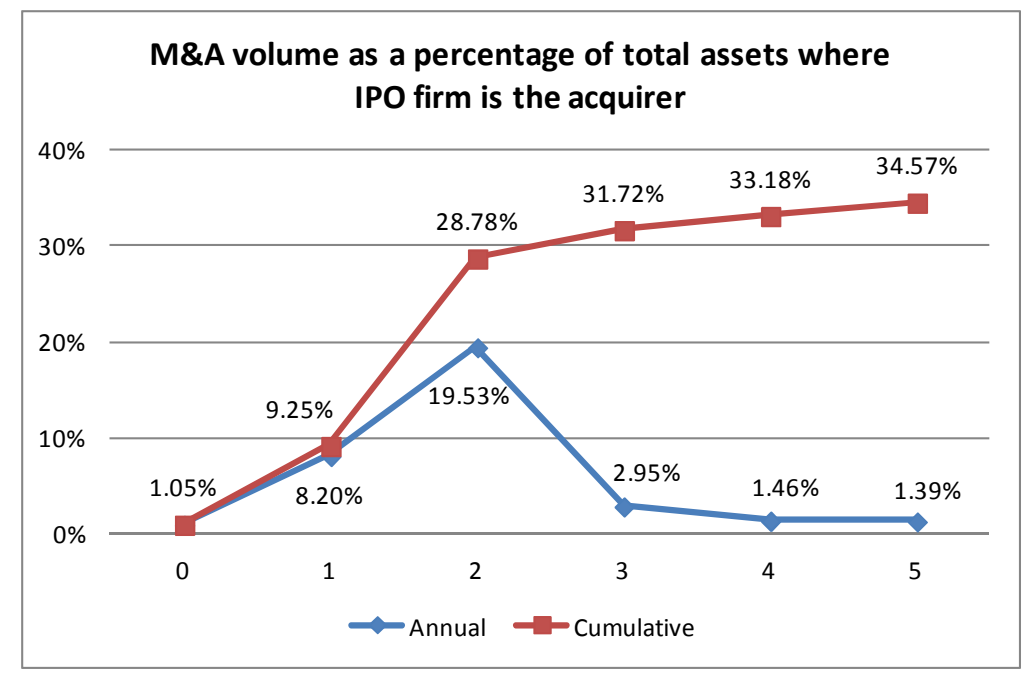

Graph 9

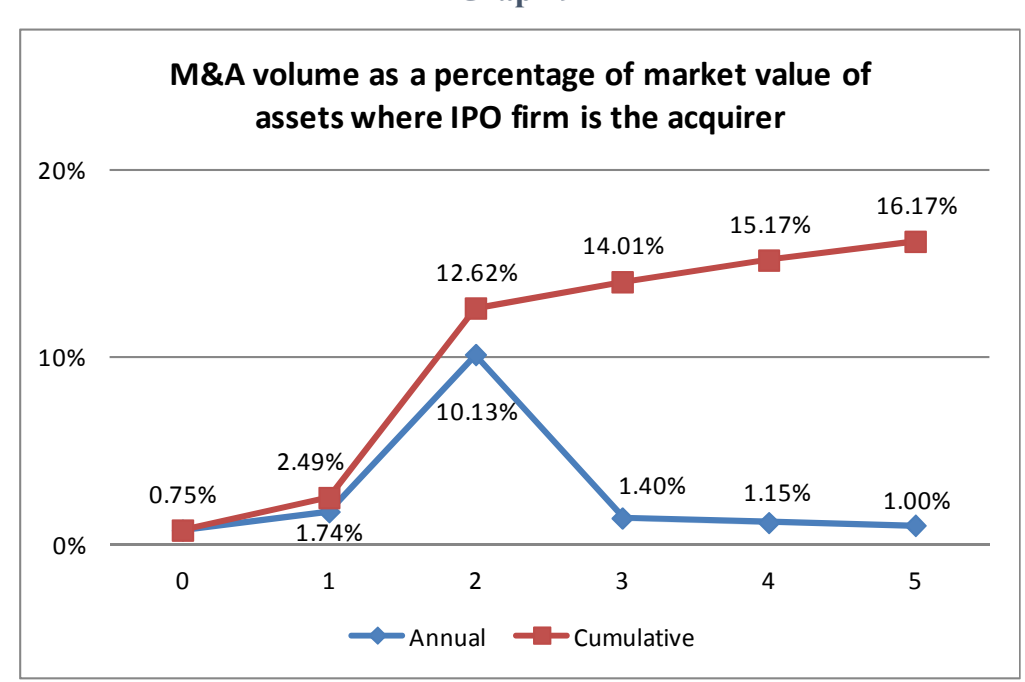


Graph 10

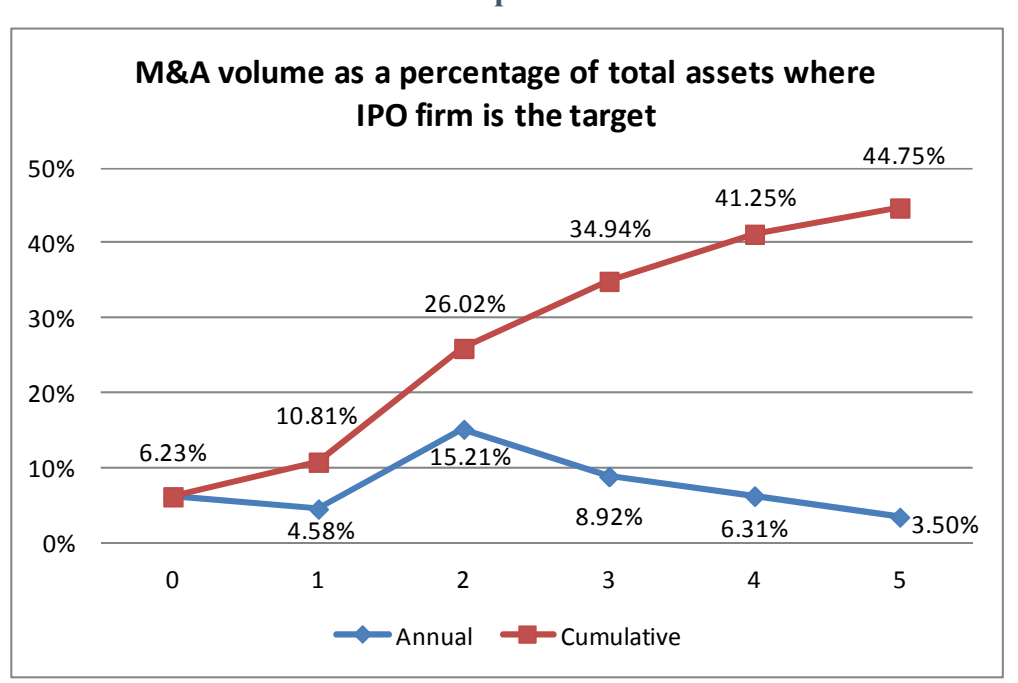

Graph 11

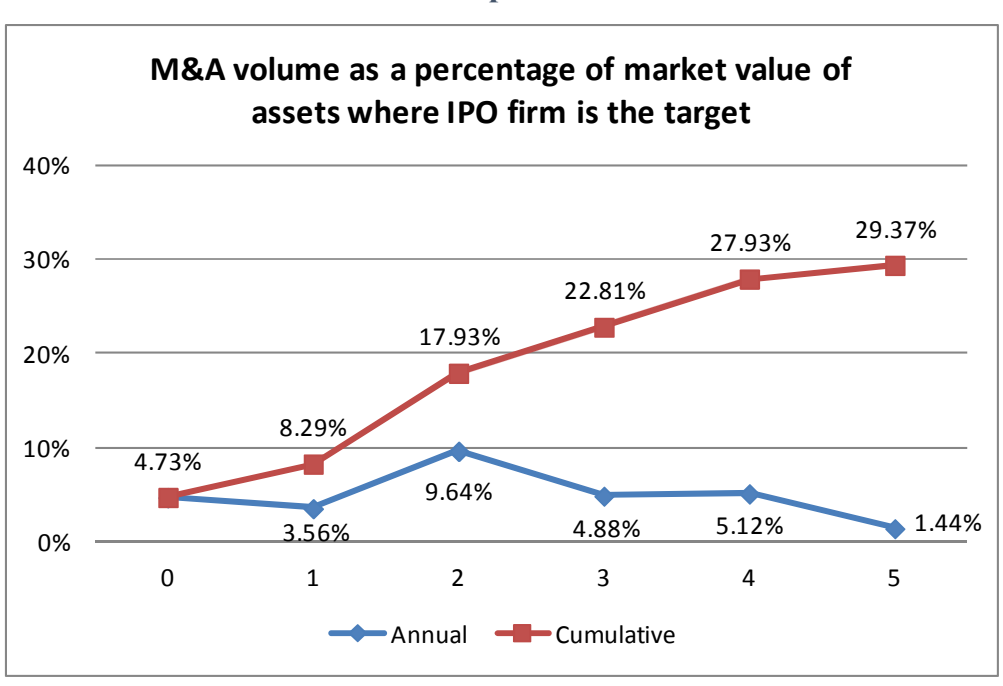

